*ak RMIS View/Frint Document Cover Sheet tow

This document was retrieved from the Documentation and Records Manaqement (DRM) ISEARCH System. It is intended for Information only and may not be the most recent or updated version. Contact a Document Service Center (see Hanford Info for locations) if you need additional retrieval information.

Accession \#: D196077724

Document \#: SD-EN-TP-057

Title/Desc:

ELECTRICAL RESISTIVITY TOMOGRAPHY FOR EARLY VADOSE LEAK DETECTION UNDER SST

Pages: 30 


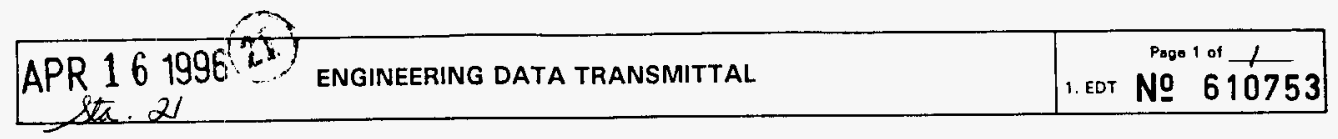

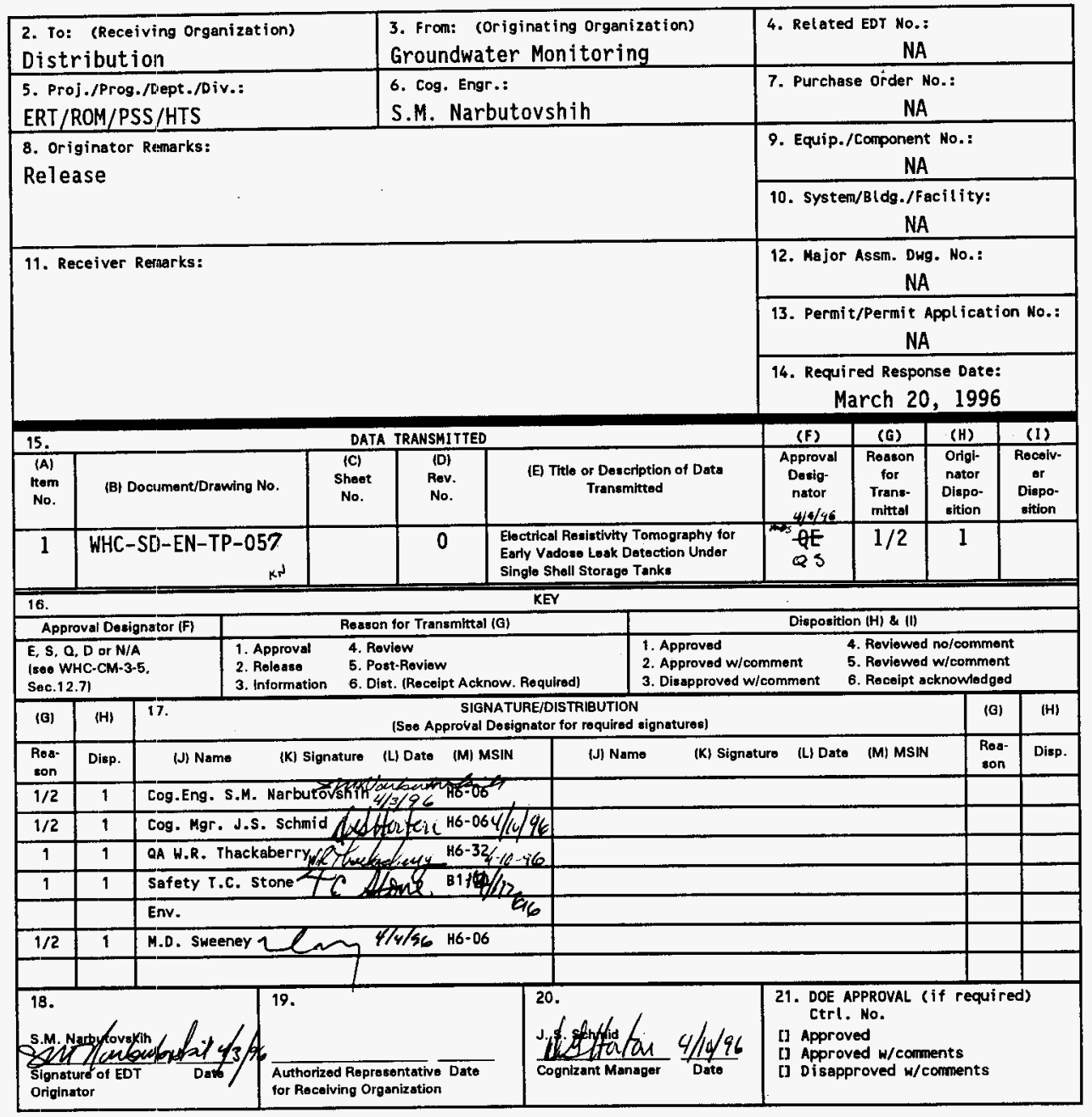

BD-7400-172-2 (04/94) GEF097 


\section{Electrical Resistivity Tomography for Early Vadose Leak Detection Under Single Shell Storage Tanks}

S. M. Narbutovskih

Westinghouse Hanford Company, Richland, WA 99352

U.S. Department of Energy Contract DE-AC06-87RL10930

EDT/ECN: 610753

Org Code: 8 H220

UC: 630

B\&R Code: EW3120100

Charge Code: $\mathrm{H} 25 \mathrm{D3}$

Total Pages: 27

kad

Key Words: vadose zone monitoring, resistivity, tomography, cone penetrometer, early leak detection

Abstract: Narbutovskih, S. M., 1996, Cone Penetrometer Demonstration at the Electrical Resistivity Tomography Site, prepared by Westinghouse Hanford Company, Richland, Washington.

TRADEMARK DISCLAIMER. Reference herein to any specific commercial product, process, or service by trade name, trademark, manufacturer, or otherwise, does not necessarily constitute or imply its endorsement, recommendation, or favoring by the United States Goverment or any agency thereof or its contractors or subcontractors.

Printed in the United States of America. To obtain copies of this document, contact: WHC/BCS Document Control Services, P.O. Box 1970, Mailstop H6-08, Richland WA 99352, Phone (509) 372-2420; Fax (509) 376-4989.
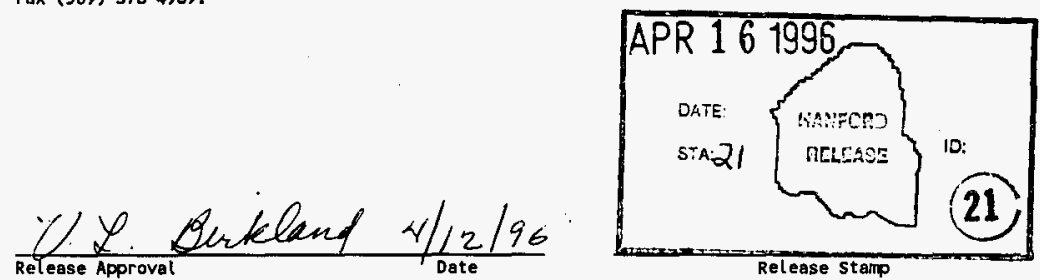


\section{CONTENTS}

1.0 INTRODUCTION ........................ 1

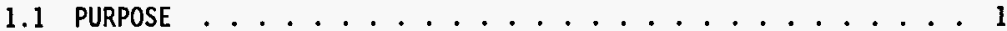

1.2 BACKGROUND . . . ............... 2

1.2 .1 ERT . . . . . . . . . . . . . . 2

1.2 .2 CPT . . . . . . . . . . . . 3

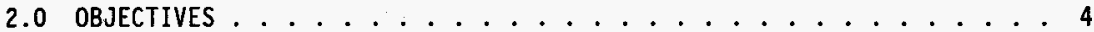

$3.0 \mathrm{SCOPE} \ldots \ldots \ldots \ldots \ldots \ldots \ldots$

4.0 DESCRIPTION OF TEST .................. 5

4.1 TECHNOLOGY DESCRIPTIONS .............. . . 9

4.1.1. Electrical Resistivity Tomography . . . . . . . . 9

4.1.2. Cone Penetrometer Technology . . . . . . . . . 10

4.2 TEST ENVIRONMENT . . . . . . . . . . . . . . . . . 13

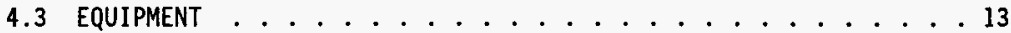

4.3.1 Electrical Resistivity Equipment . . . . . . . . 13

4.3.1.1 Two Data acquisition systems ......... 13

4.3.1.2 Scanner control boxes ............ . 15

4.3.1.3 Vertical electrode array (VEA) . . . . . . . 15

4.3.1.4 Miscellaneous Equipment ........... 15

4.3 .2 CPT Equipment . . . . . . . . . . . . . . 15

4.3.2.1 Cone Penetrometer Truck ........... 15

4.3.1.2 Cone Penetrometer Probes and Monitoring Devices

4.3.1.3 CPT Data Áquisition. . . . . . . 15

4.4 PERFORMANCE CRITERIA ................ . 16

4.5 REGULATORY COMPLIANCE ................ . . . . . . . . .

4.5.1 State Waste Discharge Permit (SWDP) . . . . . . . . 17

4.5.2 Cultural Resource Review (CRR) . . . . . . . . . 17

4.5.3 Excavation Permit .............. . . 17

4.5.4 Ecological and Historical Surveys . . . . . . . 17

4.5.5 NEPA Documentation ..................... 17

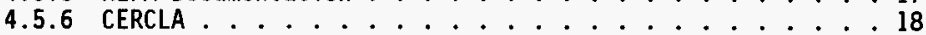

4.5 .7 RCRA . . . . . . . . . . . . . 18

5.0 WORK PROCEDURES $\ldots \ldots \ldots \ldots$

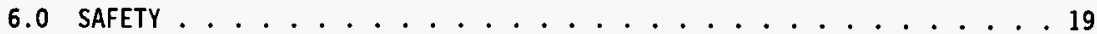

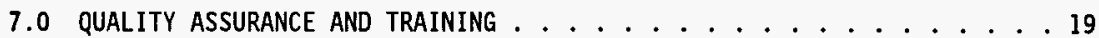

8.0 ORGANIZATION AND FUNCTION RESPONSIBILITIES . . . . . . . . . 20

8.1 Principal Investigator . . . . . . . . . . . . 20

8.2 Cognizant Engineer . . . . . . . . . . . . . . . 20

8.3 Field Team Coordinator . . . . . . . . . . . . 20

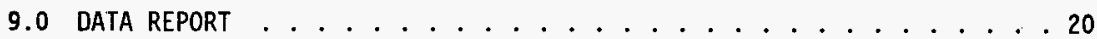

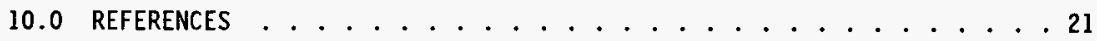


WHC-SD-EN-TP-057, Rev. 0

\section{FIGURES}

1. 200 Area 105 A Mock Tank Site Location . . . . . . . . . . . . . 6

2. Proposed CPT Locations at the 105A Mock Tank Site . . . . . . . . . . 8 8

3. Diagram exhibiting finger element details . . . . . . . . . . . . 11

4. Installation Diagram of the Finger Elements . . . . . . . . . . 12

5. Installation Diagram of the Cylindrical Elements . . . . . . . . . 14

\section{APPENDICES}

APPENDIX A TEST SCHEDULE 


\subsection{INTRODUCTION}

\subsection{PURPOSE}

This document describes planned testing with Electrical Resistivity Tomography (ERT). It is prepared in support of TTP RL46WT51 Rev. I funded by the Tank Focus Area through the Office of Technology Integration. The primary goal of the testing for fiscal year 1996 (FY96) is to develop and demonstrate the ability to place vertical electrode arrays (VEA) with the cone penetrometer technology (CPT) to depths below existing single shell tanks (SST) at the DOE Hanford Site.

It is desirable to have the capability to use CPT for this application for obvious reasons. First, current methods of emplacement, drilled boreholes, are expensive with respect to the rest of the ERT operation. Cone penetrometer VEA emplacements offer the opportunity to significantly reduce installation costs. Second, use of CPT will reduce emplacement time from weeks or months to just several days depending on the number of VEAs and the depth of placement.

ERT is preferable to other monitoring methods since operation costs and turn around time are less than the current baselines of either groundwater sampling networks or borehole logging techniques. ERT cost savings can be substantial and will continue into the future. ERT can also provide complete coverage under a tank or other facility which is an important supplement to existing monitoring methods. Groundwater sampling provides one data point per well and borehole logging provides data along a line in the ground. Neither provide information from beneath a facility and thus, are not able to locate release points. In fact, it is frequently difficult to determine which tank or facility is actually responsible for a contaminant plume in source operable units at Hanford. Locating a leak point close to the sides or base of a facility helps to determine the unit that needs remediation.

These electrode arrays are used to acquire subsurface electrical resistance data in a manner appropriate for tomographic inversion. The resulting tomograms can then be used to detect, monitor and track contaminated moisture plumes leaking from underground storage tanks during waste retrieval operations. Although ERT is a new technique, there has been sufficient field testing to demonstrate the potential and value of this method to detect subsurface resistivity changes associated with leaking contamination. However, before this technique can be effectively and economically deployed by the commercial community the development of a standardized method of electrode installation is essential. The design, prototype testing, and field demonstration of a CPT deployed VEA is the prime task of this project for FY96.

The ERT technology is a "state of the art" cross-borehole adaptation of the surface dipole-dipole resistivity method that has undergone field testing and tomographic computer code development at Lawrence Livermore National Laboratory (LLNL) to detect transient moisture changes in the vadose zone. The technique as used by LLNL is applicable for early vadose zone leak detection for hazardous waste facilities concerned with liquid migration. 
leak detection for the single-shell tanks (SSTs) during sluicing operations, long term monitoring beneath Tank Waste Remediation System (TWRS) tank farms site wide, early leak detection beneath the Waste Encapsulation Storage Facility (WESF) at B-plant, and beneath the new K-Basin Nuclear Fuel Storage Facility.

This document also supports TTP SF2-4-10-02, funded by the Innovative and Crosscutting Focus Area through the Office of Technology Development. A1though this work has three tasks, only the task relevant to the 200 East 105A Mock Tank Site at the DOE Hanford Site will be described and supported. This work includes final development and demonstration of ERT for monitoring and plume mapping under tanks with pre-existing plumes. The goal is to detect a leak and map the resulting contaminant plume beneath a tank without the benefit of the pristine baseline tomogram. The application is for subsurface environments with pre-existing steady state or nonchanging plume conditions such as the leak under $K$ Basins Solid Waste Storage Facility. Differencing of a pre-leak data set to a post-leak data set is not possible since baseline data includes an existing saturated plume. If successful, this will extend the applications of ERT to include mapping of existing contaminant plumes.

Another goal is to image a contaminant plume as it develops in a tank farm subsurface environment that has been previously contaminated by a prior leak. This is particularly useful to the tank farms at the DOE Hanford Site since borehole gamma ray logging studies indicate that subsurface radiation contamination may be wide spread. If this demonstration is successful, ERT will be ready for full-scale demonstration on a single-shell storage tank during a sluicing operation.

The level of support required for this task can easily be combined with the leak test scheduled for the second fielding of the CPT demonstration. Objectives and performance criteria will be included in evaluation reports submitted to the Innovative and Crosscutting Focus Area directly by the LLNL Principal Investigator. As such, no other discussion of the support for this task will be made except as it diverges from support being provided for the CPT demonstration.

\subsection{BACKGROUND}

Both the ERT and CPT methods are briefly discussed in this section along with a synopsis of previous deployment at the Hanford Site.

\subsubsection{ERT}

Electrical resistivity tomography is a geophysical imaging technique that maps liquids migrating through the subsurface. The fluid flow causes changes in the resistivity of the soil that are detected by introducing an electrical current into the ground through an electrode pair and measuring the resulting voltage change between another electrode pair. The ERT approach relies on detection and mapping of these resistivity variations associated with the migrating fluid. To perform an ERT survey, a number of electrodes are placed vertically in two or more borings. Several hundred resistance measurements are made between different electrodes on any two vertical electrode arrays. The data are then processed with a tomographic inversion 


$$
\text { WHC-SD-EN-TP-05F, Rev. } 0
$$

code to produce a cross-sectional image between the borings of spatial resistivity variations monitored over time. Migrating liquids appear as regions with measurable resistivity changes even when the change in saturation is only a few percent by volume.

LLNL developers have been field testing under various subsurface conditions the ERT technology for over five years (Daily and Owen, 1991; Daily et al., 1992; Daily and Ramirez, 1993; Ramirez and Daily, 1994, Ramirez et a1., 1995). At the DOE Hanford Site, the ERT technique was field tested during FY94-95 to evaluate applicability to leak detection monitoring under and around single shell tanks. The primary objective was to determine the usefulness of the technology specifically and solely for monitoring sluicing operations during waste removal (Ramirez and Daily, 1994, Ramirez et al., 1995).

The tests did not address technical concerns pertaining to any other uses for ERT, especially for long term vadose zone monitoring and plume tracking. However, results were positive for TWRS tank remediation applications. During an initial testing phase, data were collected during the discharge of approximately $4180 \mathrm{~L}$ (1100 gal) of 0.1 molar sodium chloride solution released over five days. The presence of the simulated leak was detected at the correct location around a mockup single shell tank. Furthermore, the discharged water was detected early, discerning the approximate volume of the leaked liquid (150 gal) and the resulting plume was tracked to the maximum depth of the electrode array at $11 \mathrm{~m}(35 \mathrm{ft})$.

During FY95, the RCRA and Operational Monitoring (ROM) Program sponsored a technology transfer from LLNL to the RCRA groundwater monitoring program to allow the use of ERT for various facilities at the DOE Hanford Site. This transfer from the LLNL developers to Hanford Site users required that ROM personnel gain experience in designing ERT monitoring networks, obtain and develop skills in deploying the field equipment during installation, and become proficient at data acquisition. Additionally the LLNL research tomography computer code was loaded and executed on a workstation at Hanford Technical Services (HTS). This tomography code is research oriented and required training of ROM personnel at LLNL. The result of this technology transfer is the existence of an ERT team located at the DOE Hanford Site capable of installing VEAs in the Hanford environment and acquiring, processing and interpreting ERT data. All equipment and computer needs are currently available.

\subsubsection{CPT}

The truck-mounted cone penetrometer technique was first developed to measure mechanical properties of soils. Originally a $21-t$ (23-ton) unit was built to push through heavy cobbles at a test site in Arizona. Since then, the cone penetrometer method has been developed to provide greater push capabilities with a variety of different sensor types. The system uses hydraulic rams to force a stainless steel tip into the ground. The 5-cm (2in) push rods are forced into the ground in $1.5-\mathrm{m}$ (5-ft) sections. Once the hydraul ic rams have pushed one section into the ground, the next $1.5-m$ (5-ft) section is attached and pushed. Thus, a long rod is developed that places the probe tip deeper into the subsurface. The ability to push with the hydraulics is limited by the total truck weight and the push capability of the hydraulic 
rams. The truck weight can be increased with ballast to provide approximately $27,300 \mathrm{~kg}(60,000 \mathrm{lb})$ of vertical force for cone penetration and retraction. This increase in weight is similar to the push capability of the hydraulic rams.

Since the initial development of CPT, numerous sensors have been developed to be deployed into the subsurface either in the cone tip or along the push rod. The vertical electrode string needed for ERT data acquisition represents another sensor adaptation for CPT deployment.

During FY92 and FY93, extensive testing to evaluate the feasibility of using CPT to place various sensors in the vadose zone at the Hanford Site. Due to subsurface gravel and boulder units and dry, friable sands, there was concern that a hydraulic method of sensor emplacement might not be technically possible. A brief synopsis of the test results can be found in. Narbutovskih et a1. (1996) and Rohay (1993). Although it appears that the CPT method can be used for sensor deployment down to 21 to $24 \mathrm{~m}$ (70 to $80 \mathrm{ft}$ ) depending on local geologic conditions, greater depths became significantly more challenging.

\subsection{OBJECTIVES}

The main objective of the test is to demonstrate the ability of CPT to place a series of prototype VEAs in the ground to various depths. It should be demonstrated that these electrodes can be used to acquire data sufficiently noise free to allow collection and processing of ERT data. The depths range from 27 to $49 \mathrm{~m}$ (90 to $160 \mathrm{ft}$ ) from ground surface. The depth of $27 \mathrm{~m}(90 \mathrm{ft})$ was chosen as the shallowest depth that would be acceptable for an installation in a tank farm. This is the minimum depth that would be adequate for early leak detection from the underside of a buried tank. The maximum depth of $49 \mathrm{~m}$ (160 ft) was chosen as the depth of greatest value for long term leak detection and plume migration beneath and around an entire tank farm. The maximum depth, although desirable for long term ERT goals, is of less importance for the immediate application of leak detection during a sluicing event. Thus, the maximum depth is a desirable depth, not necessarily a target depth.

Although three prototypes are currently being built and tested at the offices of Applied Research Associates (ARA), two at most will tested at the Hanford Site. The third prototype electrode array is not appropriate for the rigors of Hanford emplacements.

The field tests will occur at two separate fieldings. The first test is a preliminary 'proof of concept' test that calls for up to four VEA installations with target depths to $31 \mathrm{~m}$ (100 ft). Electrode spacing will be every $1.5 \mathrm{~m}(5 \mathrm{ft})$. This effort may require multiple attempts at more than one location to reach the target depths. Refusal criteria will be made in the field and will be at the discretion of the Field Team Coordinator in consultation with the Cognizant Engineer. To aid in installation, Tubrication of the push rod with water similar to current on-site drilling operations (Columbia River "raw" water) will be allowed. Another objective of multiple attempts is to gather information on the repeatability of placements. No more than 6 attempts will be made at any given location where it was deemed 
necessary to demonstrate repeatability.

One or both prototype VEAs will be emplaced during the initial fielding. Shortly after the arrays have been placed, they will be checked for line continuity, pole-to-pole reciprocity, and superposition (if necessary) between electrodes within an array by the WHC Field Team Coordinator and/or the Cognizant Engineer. Crosshole noise tests will also be conducted at this time, consisting of collecting reciprocal data sets similar to that for a standard, pre-leak baseline. The acquisition scheme will be determined based on installation results.

Another fielding will occur approximately one month later. This second event will consist of collecting complete tomographic data sets at a variety of horizons before and during a controlled infiltration leak. These data will then be processed and analyzed to evaluate electrode performance during data acquisition for an actual leak event. Data will be evaluated for noise content, repeatability and image quality.

Data from the CPT VEAs will be compared to data collected coincidentally with a previously placed VEA network. This older network has proven to provide high quality results for detecting small leaks in the presence of a conductive steel-based tank. The results of this comparison, along with the results of the CPT VEA placements, will be used to judge success of the overall prototype. During the time period covered by the second fielding, preliminary noise tests will be run outside a tank farm near the fence. These tests will be accomplished by placing 5 to 10 surface electrodes in a line parallel to the fence. The surface electrodes are steel rods that will be placed a few inches into the ground. The noise tests will take one to two days to conduct and results will be analyzed by LLNL to evaluate possible problems for future in-farm ERT operations. All noise tests will take place outside tank farm boundaries.

\subsection{SCOPE}

The field tests planned for FY96 consist of demonstrating the feasibility of using the CPT method to emplace a VEA to a predetermined depth for the purposes of acquiring ERT data. A variety of CPT pushes will be made at the 200 East Area 105A Mock Tank Site (Figure 1) during two fielding events. These studies are not intended to evaluate the ERT method or its applicability to early leak detection under SSTs during sluicing operations. The work planned for the current test will evaluate the feasibility of using CPT emplacements as an ERT installation technique around the Hanford SSTs.

\subsection{DESCRIPTION OF TEST}

The first fielding event is scheduled to begin in mid-Apri], 1996. Vendor staff will receive Hanford General Employee Training (HGET), if necessary, and will be provided with vendor badges on the first day's arrival. The duration of the first fielding will be approximately two weeks depending on the initial success of installation. The vendor, ARA, will place a maximum of four VEAs to depths of $31 \mathrm{~m}(100 \mathrm{ft})$. The location for these installation 
WHC-SD-EN-TP-057, Rev, 0

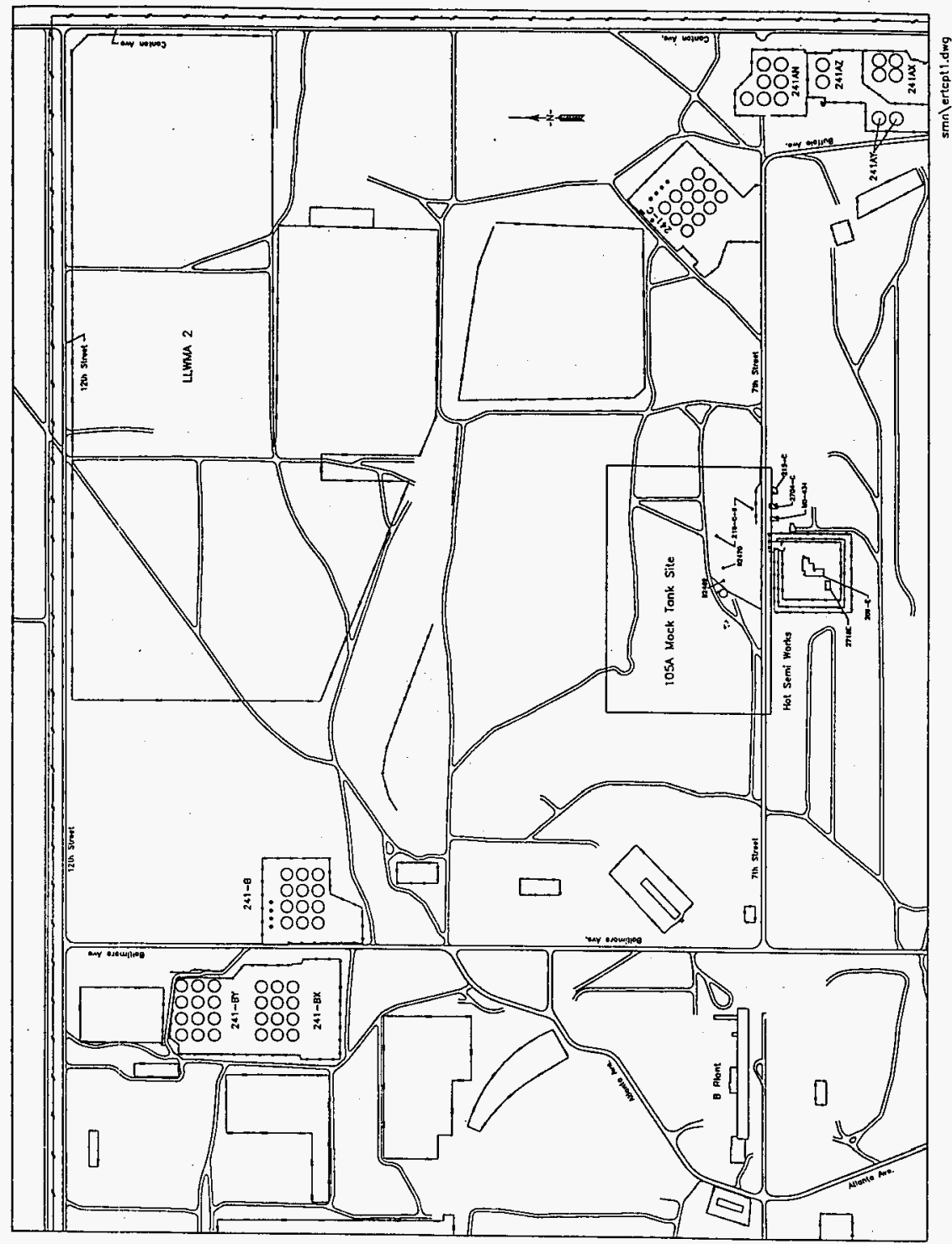

Figure 1. 200 Area 105A Mock Tank Site Location. 


$$
\text { WHC-SD-EN-TP-057, Rev. } 0
$$

is around the 105A Mock Tank Site (Figure 2). Test VEAs for these installations will have electrodes placed at five foot spacings with the deepest electrode at a depth of $31 \mathrm{~m}(100 \mathrm{ft})$ from the surface, provided these depths can be achieved. The push rod may be lubricated with raw Columbia River water during installation. Each electrode will be wetted to ensure electrical coupling as the push rod is removed unless a feeder tube is constructed and attached to the array for this purpose.

Current $\mathrm{plans}$ recommend that multiple pushes be made to evaluate CPT push repeatability with a.lubricated rod. The multiple pushes will allow the investigators to determine the success ratio that can be expected from routine operations within a tank farm. These multiple pushes may or may not have electrode arrays inside the drill rod. In addition, ARA will keep a log book to record all push attempts describing target depth, actual depth, time of lubrication, amount of water used to lubricate the drill rod, and degree of difficulty (hard, moderate, easy). Electrode testing and miscellaneous information related to daily operational activities will be recorded by the Field Team Coordinator in a separate log book. Any resistivity data collected with the CPT probe, and a copy of ARA log entries, will be given to the Field Team Coordinator on a daily basis.

The LLNL and/or WHC personnel will conduct a series of tests on these VEAs to evaluate initial performance. The Field Team Coordinator will be responsible for recording and maintaining these test data on a daily basis in the WHC log book. Pole-to-pole reciprocity and, if necessary, superposition testing within a VEA will conducted after the target depth is reached. Crosshole reciprocity tests will be performed if two or more VEAs of the same electrode design are successfully emplaced. Data may be collected for a vertical tomogram, or a series of horizontal two dimensional tomographic data sets. Provided that data are gathered during this phase, processing would occur at a later time to evaluate electrode performance. The cognizant Engineer and LLNL personnel will then develop a design criteria based on the results of the pre-leak tests.

The second fielding exercise is scheduled to begin early June, 1996. The expected duration is four to six weeks but provisions will be made to extend the period to the end of July, 1996 if required. This fielding is scheduled to gather data for electrical resistivity tomography inversion.

Each VEA will be checked for line continuity, pole-to-pole reciprocity and, if necessary, superposition by LLNL and WHC personnel. When all or most of the electrodes are functioning adequately, and if the installation warrants it, baseline ERT data may be collected for horizontal, two dimensional tomograms at a minimum of 8 horizons corresponding to those of the currently installed LLNL network. If sufficient installations reach $31 \mathrm{~m}(100 \mathrm{ft})$, then data will be collected for all horizons. Data will be collected simultaneously with both the LLNL and the WHC acquisition equipment to provide a real time comparison of equipment and method performance. In addition, data will be collected using the currently installed LLNL network to provide an independent data set from non-CPT/ERT electrodes for final comparison and evaluation. Repeated baseline data will be collected prior to leak discharge until processed, differenced baseline data sets are sufficiently free of noise. 
WHC-SD-EN-TP-057, ReV. 0

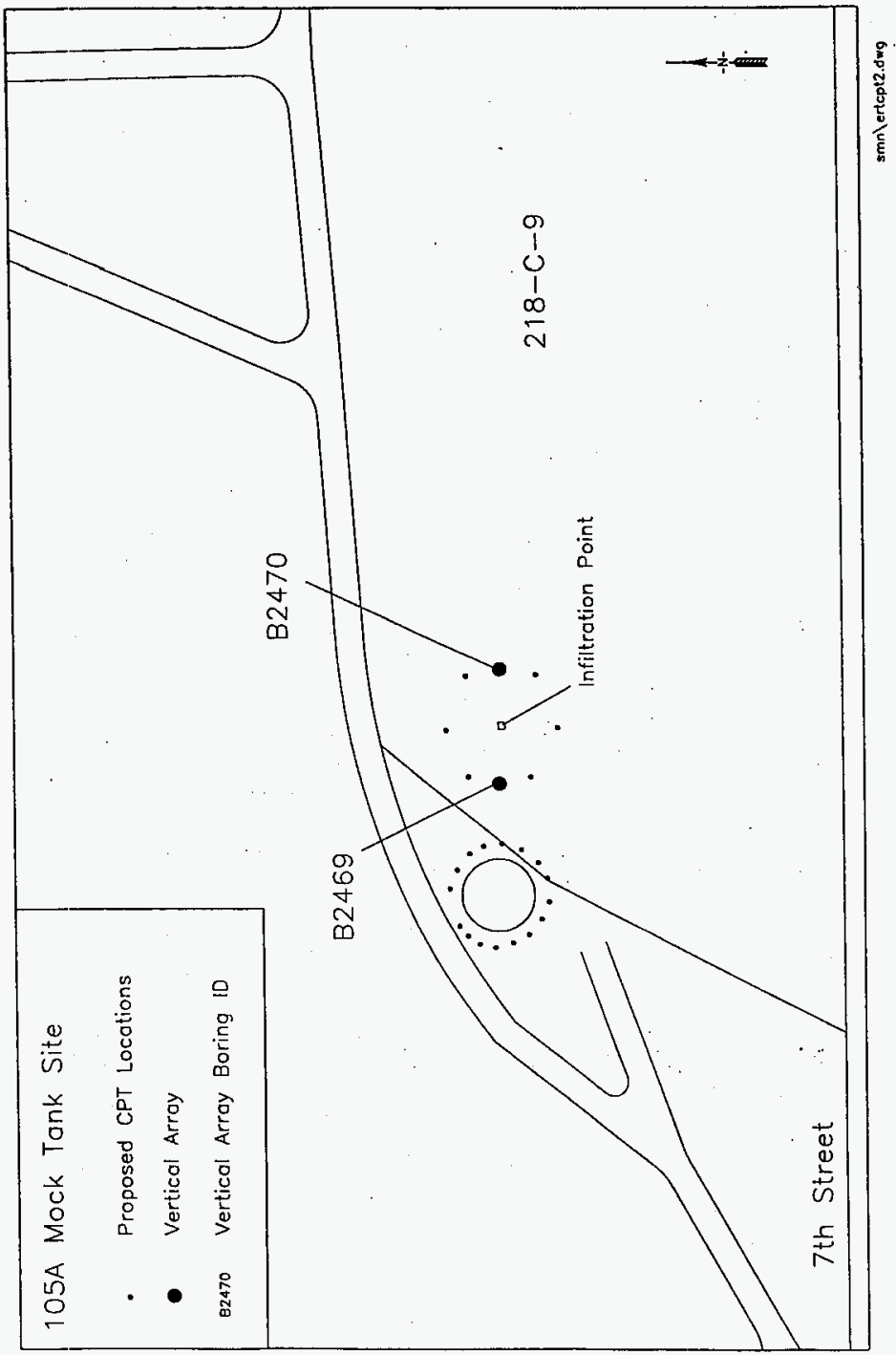

Figure 2. Proposed CPT Locations at the 105A Mock Tank Site. 


\section{and \\ WHC-SD-EN-TP-057, Rev. 0}

As data are processed, results from the CPT network, if collected, will be compared at each horizon with the results from the LLNL network. If less than four CPT VEAs are placed around the mock tank, the data obtained from the LLNL sixteen VEA network will be decimated appropriately to provide a reasonable comparison. Data sets will be evaluated and compared for clarity of image both spatially and temporally, for noise effects, for ease of processing, and for resolution.

Orice baseline data sets have been collected and processed, an aqueous solution will be released to simulate a tank leak. The solution will be discharged to the subsurface through one of the pre-installed leak points at the mock tank site. The leak event will continue for one to four weeks depending on the daily results and the depths attained by the CPT network.

The water used for leak testing may consist of raw Columbia River water, sanitary water, or a saline solution of $0.1 \mathrm{M}$ sodium chloride. The molarity of the solution may be reduced at the discretion of the Cognizant Engineer. The leakage rate will not exceed $30 \mathrm{~L} / \mathrm{hour}(8 \mathrm{gal} / \mathrm{hour})$. The total daily discharge will not exceed approximately $730 \mathrm{~L}$ (192 gal). The first leak test will cover a period of no more than two weeks and the second will be conducted for no more than four weeks. The total amount of water discharged will not exceed $38,000 \mathrm{~L}(10,000 \mathrm{gal})$. These discharges are similar to the leak testing conducted at the site in previous years. Discharges will be gaged by sight glass and tape measure, calculated for a specific unit of time. Flow rate will be recorded daily.

\subsection{TECHNOLOGY DESCRIPTIONS}

\subsubsection{Electrical Resistivity Tomography}

Electrical Resistivity Tomography is a geophysical technique for detecting leaks in the vadose zone and delineating or tracking any resulting plumes. Mapping subsurface resistivity by placing surface electrodes into the ground and measuring the change in potential at other electrodes is a standard geophysical technique for determining vertical geoelectric structure. A simple forward model of resistivity is developed and compared to the measured data. The model is refined until the calculated model results are comparable to the measured data. The "best-fit" model is considered the mostly likely representation of the subsurface resistivity structure. By contrast, ERT involves the automatic inversion, using tomographic methods, of observed electrical potentials to image spatial changes in subsurface resistivity over time with no prior knowledge of the subsurface. The result of such an inversion is an image of spatial and temporal changes in resistivity caused by migrating Tiquids.

The ERT electrodes can be placed at the surface, or in vertical subsurface arrays to collect data either between the arrays or between one vertical array and the surface depending on the information and resolution needed. The resistance values calculated from the measured potentials are processed using a 'state of the art' tomography code developed at LLNL. The material property of electrical resistivity is useful to delineate movement of water or other conductive fluids through a resistive vadose zone. Recent work done by LLNL scientists at the 200 East Area 105A Mock Tank Site has 
WHC-SD-EN-TP-057, Rev. 0

demonstrated that the use of ERT, when properly applied, allows for early detection and mapping of saline solutions percolating through the vadose zone under and around underground storage facilities. Leaks as small as $570 \mathrm{~L}$ (150 ga1) could be detected with resolution estimated at $4.5 \mathrm{~m}(15 \mathrm{ft})$.

When the objective is to detect and map new leaks in the vadose zone, ERT applications involve two phases. The first phase measures the background resistivity structure associated with spatial moisture changes caused by lithologic variations. Once a leak has occurred, a second phase data set is collected in the same manner and it is compared to the original background data. The differences between the two data sets delineates the migrating liquid. This ERT application allows the removal of unwanted electrical signal from nearby buried steel objects such as steel-cased boreholes or steel tanks.

\subsubsection{Cone Penetrometer Technology}

There are three major components to a CPT rig. The first part is the hydraulic system discussed in Sections 1.2 .2 and 4.3.2.1. The second consists of the push rods and the sensor probes. For the ERT VEAs, this consists of the wireline cable with the attached electrodes strung inside the 5-foot sections of push rods. A truck-mounted 486 computer with amplifiers, filters and analog-to-digital (A/D) data board comprises the third part of the overall CPT system.

Sensor probe design for the first fielding has produced three different prototypes for emplacement. Only two of the prototypes were deemed durable enough to withstand emplacements at Hanford. One or both of these prototypes will be tested at Hanford. The prototype to be tested is constructed of stainless steel finger probes cut from stainless tempered stock and silver soldered to a stainless steel 1.4-cm (9/16-in) hose clamp (Figure 3). Each ERT finger element is slid onto a multi conductor cable and the hose clamp is crimped tightly to hold the assembiy in place. A small slit is made through the outer jacket of the multiconductor cable and a predetermined color coded wire is fished from the bundle, cut, and the upstream end stripped and soldered to the finger assembly. This end of the element is then sealed with a self-fusing tape. The fingers are normally spaced $1-m$ on center and measure $18-\mathrm{cm}$ by $0.6-\mathrm{cm}$ by $0.05-\mathrm{cm}$ (7-in by $1 / 4-$ in by $0.020-\mathrm{in}$ )

The installation will involve folding the stainless fingers close to the multiconductor cable with the fingers pointed upward so that they will point toward the ground surface during the push. The finger assembly is threaded through a $4.5-\mathrm{cm}(1.75-i n)$ diameter push rod with a conical tip at the base (Figure 4). The tip is slightly wider than $4.5-\mathrm{cm}(1.75-i n)$ which enhances the extraction of the push rod and anchors the multiconductor wire to the soil. The multiconductor wire is attached to the top of the tip with silver solder. As the tip is advanced into the soil, the finger assembly is advanced with it until total depth is reached. The push rod is then extracted and the fingers deployed by expanding against the collapsing sediments (Figure 4).

The second prototype proposed for ERT applications is also constructed from spring stainless steel sheet and has silver soldered contacts. It is installed the same as the finger electrodes. The second probe differs in the geometry of the element. Instead of long fingers, the second design incorporates cylindrical elements composed of conical sections that expand 


\section{ERT Stainless Steel "Finger Element" Assembly Drawing}

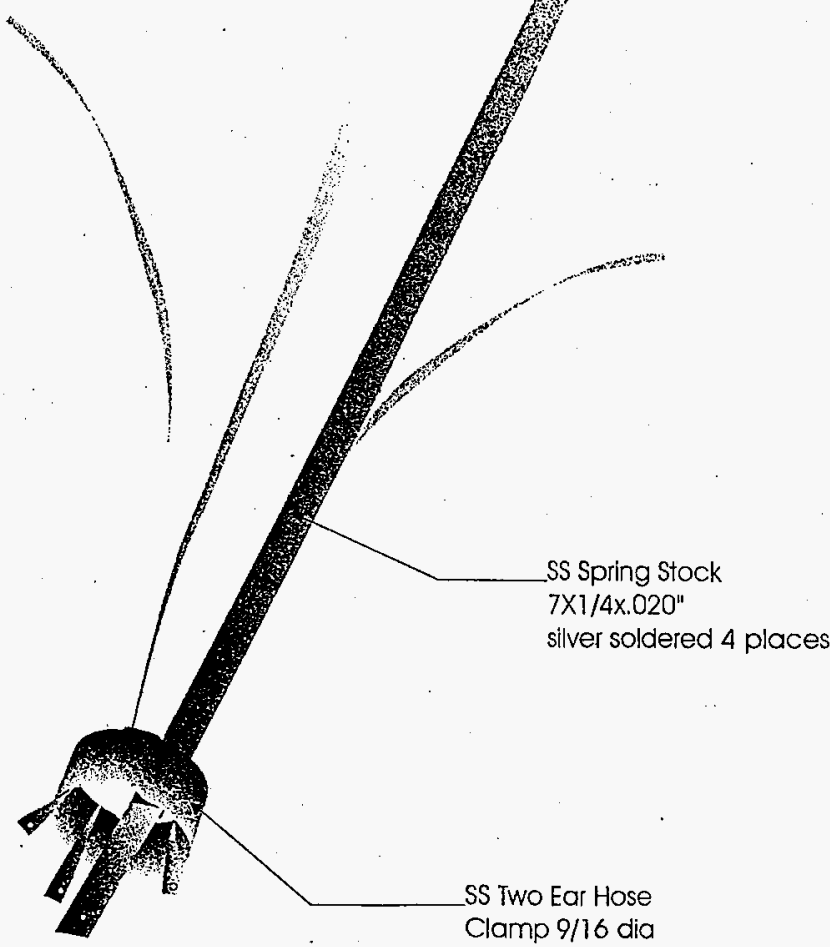

Figure 3. Diagram exhibiting finger element details. 


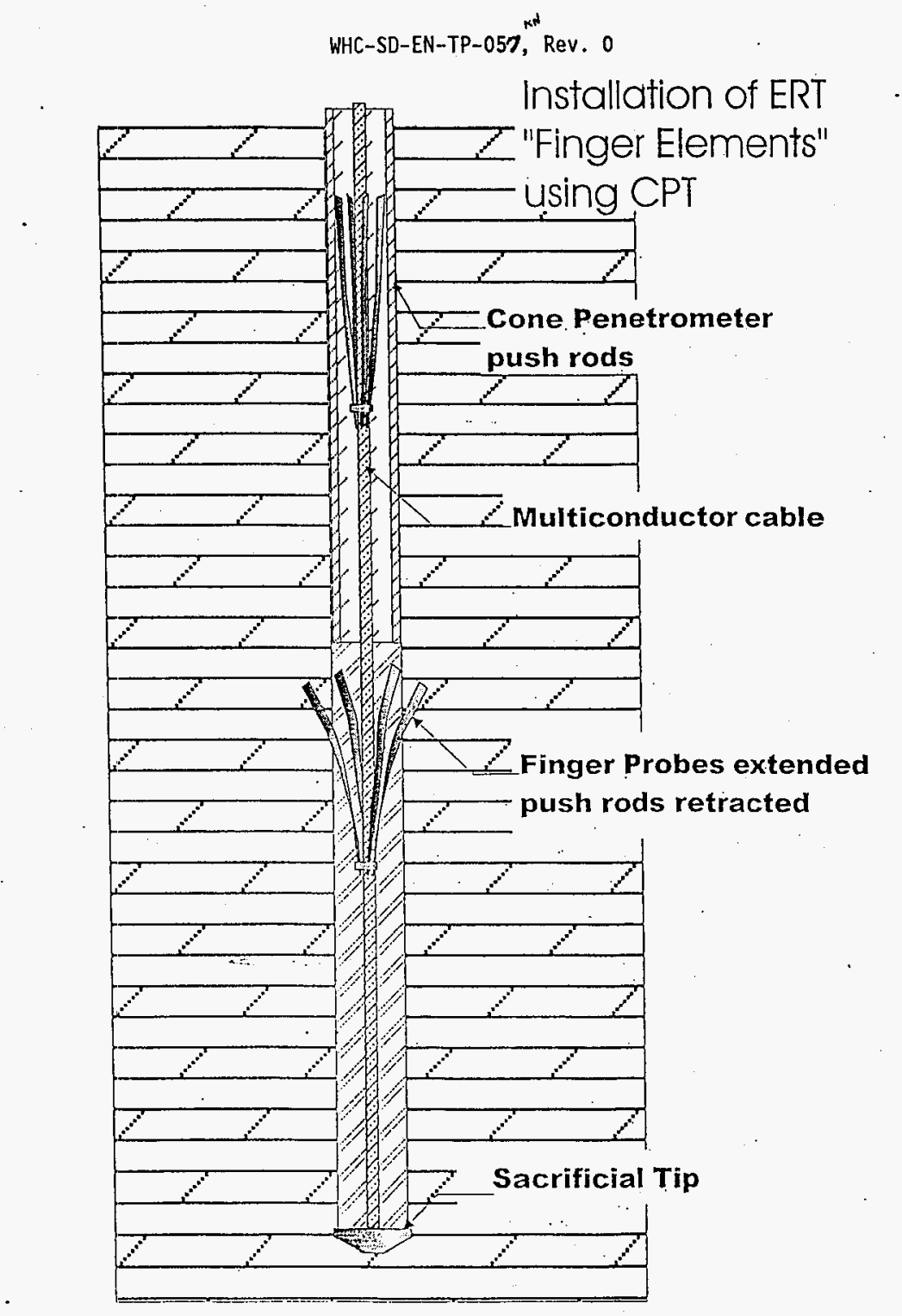

Figure 4. Installation Diagram of the Finger Elements. 
during deployment to make contact with the surrounding soil (Figure 5). The conical sections are constructed of stainless steel cut into trapezoids. These trapezoids are then wrapped around the multiconductor wire in a conical shape pointed toward the bottom of the hole. The down pointing cones are designed to avoid snagging on the push rod joints as the rod is removed. The electrodes are attached to the multiconductor cable in an identical manner to the finger elements (see Section 4.1.2).

During extraction, the conical elements expand into the borehole assuming a cylindrical shape. These cylinders have the advantage of a greater surface area and should increase electrical coupling with the surrounding soil.

The data acquisition system for the CPT hydraulics is provided by the on-board computer, signal amplifiers and filters and $A / D$ converters. The computer is usually used to automatically collect data from the deployed CPT sensors. Signal amplifiers and filters condition the signal retrieved from the network to provide measurable inputs for the $A / D$ converter. Output from the $A / D$ converter constitutes the final measurable signal and input for the computer. For this test, no data from the electrodes will collected with this system.

\subsection{TEST ENVIRONMENT}

The CPT VEA tests will be conducted at the 200 East 105A Mock Tank Site where previous ERT tests have been conducted (Figure 1). This test site was prepared and a1l work documented in Iwatate (1994).

The test environment for the first ERT fielding will consist of a network composed of 4 to 8 VEA placed approximately $24 \mathrm{~m}(80 \mathrm{ft})$ apart with depths to $49 \mathrm{~m}(160 \mathrm{ft})$. Two VEAs were placed in FY95 during the technology transfer project sponsored by the ROM program (WHC 1995a). The remaining 2 to 6 VEAs will be installed during the first fielding. A permanent infiltration point was constructed during the FY95 fielding positioned in the center of the proposed location of this network. The infiltration point consists of three $10-\mathrm{cm}(4-\mathrm{in})$ PVC pipes placed $2.4 \mathrm{~m}(8 \mathrm{ft})$ into the subsurface and interconnected by a $2.5-\mathrm{cm}(1-i n)$ PVC water supply Tine. This system is used to introduce water at a controlled flow rate to simulate an artificial leak to the subsurface.

The current VEA installations around the mock tank itself are described in Ramirez et a1. (1995).

\subsection{EQUIPMENT}

\subsubsection{Electrical Resistivity Equipment}

The equipment involved in the acquisition of ERT data is described in the following sections.

4.3.1.1 Two Data acquisition systems. The first system, operated by WHC personnel, consists of an central transmitter/receiver unit with an output 
kn

WHC-SD-EN-TP-057, Rev. 0

\section{BEST AVAILABLE COPY}

\section{Expanding Cylindrical Electrode}

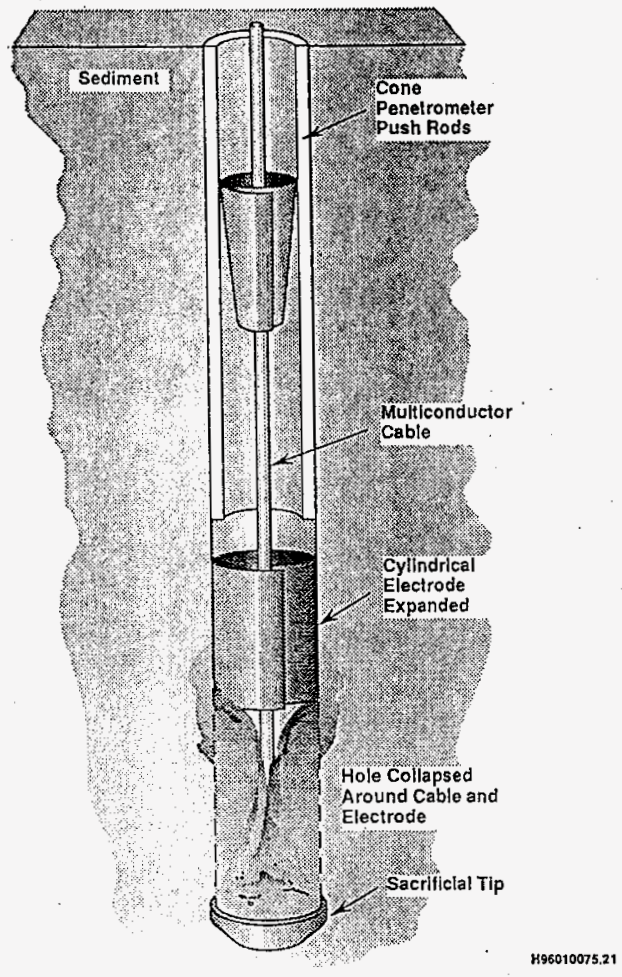

Figure 5. Installation Diagram of the Cylindrical Elements. 
WHC-SD-EN-TP-057, Rev. 0

voltage of 200 volts and a constant current that can be set from 1 to 200 milliamps. Input power requirements are 12 volts DC with a 10 amp maximum.

Data will be collected simultaneously with a data acquisition system operated by LLNL personnel. The system used by LLNL consists of a transmitter and a receiver with a switched $D C$ output that delivers a peak-to-peak voltage of 100 volts at approximately 300 milliamps. The switched voltage can be varied in frequency from $1 \mathrm{~Hz}$ to $1 \mathrm{KHz}$.

4.3.1.2 Scanner control boxes. The scanner control boxes consist of switching relays that control the switch over of the electrodes in a borehole or at the surface. Up to 32 electrodes can be switched automatically.

4.3.1.3 Vertical electrode array (VEA). Vertical Electrode Array networks consisting of 8 to 16 electrodes at $1.5 \mathrm{~m}$ to $3 \mathrm{~m}$ ( $5 \mathrm{ft}$ to $10 \mathrm{ft}$ ) spacing. One network will be around the RCRA infiltration installation and the other networks will surround the mock tank site.

4.3.1.4 Miscellaneous Equipment. Four reels of insulated wire. will be used to connect to remote electrodes. A 40 amp power supply will be on-site to provide power for the acquisition equipment. Primary power (120 \& 220 VAC) will be supplied by a portable generator.

\subsubsection{CPT Equipment}

4.3.2.1 Cone Penetrometer Truck. The modified CPT truck uses ballast to gain additional mass to push the rod to greater depths. The standard weight of the ARA CPT truck is $22,075 \mathrm{~kg}(48,660 \mathrm{lb})$. With equipment and supplies, the truck weighs $24,150 \mathrm{~kg}(53,250 \mathrm{lb})$. For Hanford Site work, the weight has been increased by an additional $6,350 \mathrm{~kg}(14,000 \mathrm{lb})$ through the addition of lead weights. This has resulted in a total truck weight of approximately $30,390 \mathrm{~kg}(67,000 \mathrm{lb})$. In the standard configuration, this CPT truck is capable of pushing up to $90 \%$ of the total weight. The push capability is limited by the hydraulic rams, which are capable of pushing approximately $27,270 \mathrm{~kg}(60,000 \mathrm{lb})$. As configured, the truck is capable of operating at its maximum push capability.

Ballast compartments have been added to the CPT truck since the fiscal year (FY) 1992 demonstration. The lead ballast is encased in steel, air-tight boxes that are loaded into the compartments using a fork iff. This advancement has reduced potential worker exposure to lead and decreased the time required to laad the ballast. Improved balance also increase the CPT's potential push capability by four percent.

4.3.1.2 Cone Penetrometer Probes and Monitoring Devices. The standard penetrometer assembly has a $3.57-\mathrm{cm}(1.405-\mathrm{in})$ outer diameter (00), a $1.59-\mathrm{cm}$ (0.625-in) inner diameter (ID), a 60-degree angle conical tip, and a friction sleeve $3.57-\mathrm{cm}(1.405-\mathrm{in})$ in diameter and $13.23-\mathrm{cm}(5.21-\mathrm{in})$ iong. Push rods used to advance the probe may have a $3.57-\mathrm{cm}(1.405-\mathrm{in}), 4.45-\mathrm{cm}$ (1.75-in), or $5.08-\mathrm{cm}(2.0-\mathrm{in}) \mathrm{OD}$. The larger diameter $\{4.45-\mathrm{cm}(1.75-\mathrm{in})$ and $5.08-\mathrm{cm}(2.0-$ in)] rods have room to accommodate a grouting tube and the wiring cable required for the probe instruments; the grouting tube is attached to the $3.57-$ $\mathrm{cm}(1.405-\mathrm{in})$ diameter probe with an adapter. The 4.45-cm (1.75-in) OD rod 
has a yield strength of $49,000 \mathrm{~kg}(108,000 \mathrm{lb})$, compared to the $3.57-\mathrm{cm}$ (1.405-in) standard CPT rod, which has a yield strength of $21,775 \mathrm{~kg}(48,000$ 1b). For this reason, the $4.45-\mathrm{cm}(1.75-\mathrm{in})$ rod will be used during the $F Y$ 1996 operations.

4.3.1.3 CPT Data Acquisition. Electronic data acquisition equipment for the cone penetration consists of a computer with a graphics monitor and a rack of eight signal conditioners. Analog signals are transmitted from the probe to the signal conditioners where the data are amplified and filtered at $1 \mathrm{~Hz}$.

Once amplified, the analog signals are transmitted to a high-speed $A / D$ converter board where the signals are digitized, usually at the rate of one sample per second for penetrations data. These data can be observed on the monitor during the push. The digital data are then read into memory and written to the internal hard disk for future processing. Upon completion of the test, the data are plotted.

As a quality-control measure, and as a check for instrument damage, the load cells and the pressure transducer are routinely calibrated in the field. Calibrations are completed with the probe ready to insert into the ground so that factors affecting any component of the instrumentation system will be detected and isolated during the calibration.

\subsection{PERFORMANCE CRITERIA}

The primary objective of this year's work is to demonstrate CPT deployment of VEAs that will be used to collect ERT data. The criteria for evaluating success are described below.

It should be demonstrated that deployment of at least 8 VEAs to a minimum depth of $24 \mathrm{~m}$ ( $80 \mathrm{ft}$ ) around the mock tank site be achieved with no more than 3 attempts for each VEA. These installations are part of the second fielding. The minimum depth was chosen based on the tank depths at the BY tank farm. The bottom of the tanks are $15 \mathrm{~m}(50 \mathrm{ft})$ below the surface. An additional $9 \mathrm{~m}(30 \mathrm{ft})$ was added to keep electrodes sufficiently below the tank bottom to avoid noise effects from the conductive steel bottom and still a) low multiple horizon coverage.

At least 80 percent of the electrodes should be able to receive and send signals. No more than one electrode should be nonfunctioning for any single horizon, and there should be data from no less than 7 .electrodes available for each horizontal tomogram. The intra-array and inter-array reciprocal tests should exhibit differences of less than two percent. The amplitudes of the received potentials should be similar to those collected with either the RCRA or LLNL networks. Furthermore, tests for superposition will be conducted, if needed, and the results recorded.

Finally, the tomographic images produced from data collected with the CPT network during the leak test at the mock tank site should compare favorably with the corresponding data from the LLNL network. The LLNL data set will be decimated to produce data from 8 electrodes per horizon. Furthermore, allowances will be made for differences in geometry and VEA spacing which will affect resolution. 
WHC-SD-EN-TP-057, Rev. 0

\subsection{REGULATORY COMPLIANCE}

\subsubsection{State Waste Discharge Permit (SWDP)}

At the request of the Washington State Department of Ecology (Ecology), the permit for waters discharged to ground for this study is covered under Categorical one-time/limited duration WAC 173-216 Permit Applications No. 1 described under the Plan and Schedule for Disposition and Regulatory Compliance for Miscellaneous Streams (DOE 1994). The following limitations exist:

1. effluent discharges must be less than 381 iters per minute (10 gallons per minute) averaged annually,

2. effluent discharges must be less than 568 liters per minute (150 gallons per minute) maximum instantaneous discharge rate,

3. effluent discharges must not be greater than 54,888 liters per day $(14,500$ gallons per day).

\subsubsection{Cultural Resource Review (CRR)}

A Cultural Resource Review (CRR) was performed for the 105A Mock Tank Site prior to initial construction. The site is within an area that had been previously disturbed by building construction and, therefore, did not pose any new or significant issues in this regard. A copy of the CRR can be found in the Appendix $H$ of Iwatate (1994).

\subsubsection{Excavation Permit}

An Excavation Permit will be obtained and will include not only the CRR but also any requirements for a Radiation Work Permit (RWP).

\subsubsection{Ecological and Historical Surveys}

Ecological and Historical Surveys were conducted in support the 200 East Area 105A Mock Tank Site modifications in 1994. No plant or wildlife species would be impacted by the proposed work activities associated with the ERT project. In the Historical Survey, it was found that the 105A Mock Tank Site had not been used for any operational purpose. Solid waste burial grounds are located to the north but are distant enough to have no probable impact of tracer studies. Documentation on the Ecological Survey can be found in Appendix $J$ and the Historical Survey in Appendix K of Iwatate (1994).

\subsubsection{NEPA Documentation}

The National Environmental Policy Act (NEPA), 42 USC 4321 et seq., is the basic federal charter for protecting the nation's environment. NEPA's focus is to ensure that federal agencies, such as DOE, give appropriate consideration to environmental impacts in their decision-making. 
NEPA compliance for this demonstration is achieved by reference to DOE's determination of December 4, 1992 that characterization and environmental monitoring activities on the Hanford Site fit within a typical class of action currently available for Categorical Exclusion (CX) in Subpart $D$ of the $U$. $S$. DOE NEPA Implementing Procedures, 10 CFR Part 1021. While site characterization is not the central purpose of the demonstration activities described in this integrated test plan, these activities will produce data and information that will be useful for characterization of the environmental conditions of the 200 Area Mock Tank Site (Figure 1).

The minimal environmental impacts that these demonstration activities are likely to cause are well within the impacts described in the materials supporting that $C X$ determination. Prior to initiation of the activities under this test plan, detailed cultural and biological resource reviews will have been performed and all 10 CFR Part 1021 requirements and all other conditions stated in DOE's categorical exclusion determination will have been fulfilled. Therefore, the demonstration activities described in this test plan need no further NEPA review and documentation.

\subsubsection{CERCLA}

The Comprehensive Environmental Response, Compensation, and Liability Act (CERCLA), 42 USC 9601 et seq., is designed to manage the unplanned and uncontrolled releases of hazardous substances. In particular, CERCLA is the governing framework for the Environmental Restoration Program at Hanford Site. Depending on test results, the data generated could contribute to environmental restoration site characterization.

\subsubsection{RCRA}

Subtitle C of RCRA, 42 USC 6921-6939b, establishes a comprehensive program to regulate newly generated hazardous waste. Administered by Ecology and the U. S. Environmental Protection Agency (EPA), RCRA Subtitle C requirements are contained in Chapter 173-303, Washington Administrative Code, and in 40 CFR Parts 260 through 272, and apply to the generation, accumulation, treatment, storage, and disposal of hazardous waste. No solid, hazardous, or mixed wastes are expected to be generated by this test. In the event such wastes are generated, they will be managed in accordance with applicable RCRA requirements, including WHC Environmental Investigations Instruction (EII) 4.2, "Interim Control of Unknown, Suspected Hazardous, and Mixed Waste" (WHC 1988a).

\subsection{WORK PROCEDURES}

Established work procedures will be used to achieve the objectives outlined in Section 4.4. Work practices will follow EII 3.5 (WHC 1988a). Abandonment of penetrometers that cannot be retrieved for any reason will follow Washington State Department of Ecology (Ecology) regulations (Ecology 1990).

The ease of installation, durability, and functional reliability of the 
cable and electrode arrays will be evaluated. In particular, the connector between the vertical electrode array and the acquisition cable is of concern. The acquisition network, which includes the acquisition instrument and the two scanner boxes, will be evaluated for field durability, data acquisition speed, equipment reliability, ease-of-use, and in-field quality control capabilities. The procedure will include documentation of performance with respect to these characteristics.

Due to the unique nature of this investigation, there are no current industry standards or WHC procedures for performing ERT acquisition and processing. This project will rely on previous techniques and methods provided by LLNL.

\subsection{SAFETY}

Activities under this work test plan will be governed by the SiteSpecific Job Hazard Analys is for the 105A Mock Tank Site. The work site is not in a radiation zone and Health Physics coverage will be governed by the Excavation Permit. The remaining work after the installation of the electrodes will be covered by a Job-Specific Job Hazard Analysis.

\subsection{QUALITY ASSURANCE AND TRAINING}

All work on the Hanford Site is subject to the requirements of DOE Order 5700.6C, Quality Assurance (DOE 1991), which establishes broadly applicable Quality Assurance (QA) program requirements.

To ensure that the technology transfer activities are consistent with DOE Order 5700, Quality Assurance, all work will be performed in compliance with WHC's Quality Assurance (QA) manual, WHC-CM-4-2 (WHC 1988b) and with applicable procedures outlined in the QA Program Plan (WHC 1995b). This QA program $p l a n$ describes the various plans, procedures, and instructions that wiTl be used by WHC to implement the requirement of DOE Order $5700.6 \mathrm{C}$.

ARA shall maintain the CPT in a calibrated condition and shall furnish evidence of satisfactory calibration at the conclusion of each task package. ARA shall also grant access to the premises, files, procedures and records associated with this test plan for the purposes of WHC Quality Assurance audits and/or surveillance.

The objective of the test plan is to ensure that the data obtained and the conclusions drawn are sufficiently accurate and reliable to support decisions associated with the evaluation of the technology transfer and associated objectives.

No special training will be required for personnel not entering radiological zones. However, standard training, including the Occupational Health and Safety Administration (OSHA) training for personnel working at hazardous waste sites, plus all relevant training required for specific radiological zones, will be required for any personnel entering these zones. ARA personnel directly involved in emplacement of penetrometers will have 
training and experience consistent with EII 3.5 (WHC 1988a).

\subsection{ORGANIZATION AND FUNCTION RESPONSIBILITIES}

Field work will be performed by ARA and LLNL personnel working with the Cognizant Engineer and the Field Team Coordinator. General and specific responsibilities for the field work constituting the technology demonstration are outlined in the following sections.

\subsection{Principal Investigator}

The principal investigator ensures regulatory and Hanford-specific compliance for field demonstration activities. The Principle Investigator will prepare a performance evaluation report that presents the results of the field demonstration for testing related to each objective.

\subsection{Cognizant Engineer}

The cognizant engineer is responsible for conduct of field demonstrations. The Cognizant Engineer is also responsible for coordinating with the Principal Investigator and the Field Team Coordinator to ensure the availability of needed equipment and materials. The Cognizant Engineer will, with the assistance of the Principal Investigator:

- ensure that the work objectives are met

- conduct the work in a coordinated effort with the Field Team Coordinator, ARA and LLNL personnel

- provide personnel to assist in setting up equipment.

- provide personnel to execute electrode testing and analyze the results for ERT work.

The Cognizant Engineer can, as necessary, delegate part or all of these responsibilities to the Field Team Coordinator.

\subsection{Field Team Coordinator}

The Field Team Coordinator is responsible for overall technical field management of the project and control of site access. All on site personnel report to the Field Team Coordinator to accomplish their work. The Field Team Coordinator is responsible for final operations and the final conditions of any abandoned CPT push hole. The Field Team Coordinator will also be responsible for recording field activities on a daily basis in a log book, and for taking the necessary measurements to determine VEA performance as described in Section 4.0.

\subsection{DATA REPORT}

A data report will be published at the completion of ERT testing at the 
105A Mock Tank Site. The data report will contain summarized information derived from CPT installations, electrical resistivity measurements and daily entries from the log book. This report will be published near the end of FY96.

\subsection{REFERENCES}

Daily, William and Earle Owen, 1991, Cross-borehole Resistivity Tomography, Geophysics, Vol. 56, No. 8, pp. 1228-1235, August 1991.

Daily, William, Abelardo Ramirez, Douglas La Brecque, and John Nitao, 1992, Electrical Resistivity Tomography of Vadose Water Movement, Water Resources Research, Vol. 28, No. 5, pp. 1429-1442, May 1992.

Daily, William and Abelardo Ramirez, 1993, Electrical Resistance Tomography During In Situ Remediation of a TCE Plume at the U.S. Department of Energy Savanna River Site; Proceedings of the Symposium on the Application of Geophysics to Engineering and Environmental Problems, Vol. 1, pp. 51-52, Apri1 1993.

Ecology, 1990, Minimum Standards For Construction and Maintenance of Wells, Chapter 173-160 WAC, Abandonment of uncased wells, 173-160-420, Washington State Department of Ecology, Olympia, Washington.

DOE Order 5700.6C, Quality Assurance, U.S. Department of Energy, Richland Operations Office, Richland, Washington.

DOE-RL, 1994, Plan and Schedule for Disposition and Regulatory Compliance for Miscellaneous Streams, DOE/RL-93-94, U.S. Department of Energy, Richland Operations Office, Richland, Washington.

Internal Memo, D. F. Iwatate to L. A. Fort, "Completion of FY-95 Deliverable/Milestone: Electrical Resistance Tomography Evaluation Letter Report", dated September 29, 1994.

Narbutovskih, Susan, Deborah Iwatate, William Daily, Abelardo Ramirez, Rex Morey, Daniel Mendoza, Feasibility of Cone Penetrometer-Deployed Vertical Electrode Arrays in Single-She 17 Tank Farms, WHC-SD-EN-TA-004, Westinghouse Hanford Company, Richland Washington, (in preparation).

Ramirez, Abelardo, William Daily, Douglas La Brecque, Earle Owen, and D. Chesnut, Monitoring an Underground Steam Injection Process Using Electrical Resistance Tomography, Water Resources Research, Vol. 29, No. 1, p. 73-87, January 1992.

Ramirez, Abelardo and William Daily, Andrew Binley, Douglas La Brecque, and David Roelant, 1995, Detection of Leaks in Underground Storage Tanks Using Electrical Resistance Methods, UCRL-JC-122180, Lawrence Livermore National Laboratory, Livermore, California, in publication.

Rohay, V. J., 1993, Electronic Cone Penetration Testing at the Hanford Site, 200 West Area, WHC-SD-EN-TI-171, Westinghouse Hanford Company, Richland, Washington. 
WHC, 1988a, Environmental Investigation Instructions, WHC-CM-7-7, Westinghouse Hanford Company, Richland, Washington.

WHC, 1988b, Quality Assurance, WHC-CM-4-2, Westinghouse Hanford Company, Richland, Washington.

WHC, 1995b, Environmental Engineering Technology and Permitting Function Quality Assurance Program Plan, Section 1.5, WHC-IP-1052, Westinghouse Hanford Company, Richland, Washington.

WHC, 1995a, Electrical Resistivity Tomography at the DOE Hanford Site, WHC-SA3035-VA, Westinghouse Hanford Company, Richland, Washington. 
WHC-SD-EN-TP-057, Rev. 0

\section{APPENDIX A}

\section{TEST SCHEDULE}




\section{$\vdots \quad$ Mark $\rightarrow$ Reps sekeducke}

WHC-SD-EN-TP-057, Rev. D rork schedule

RA Inc. CPT Crew at Hantord

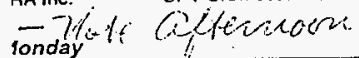

\begin{tabular}{|c|c|}
\hline ime & Plan \\
\hline \multirow[t]{2}{*}{$78: 00-9: 00$} & \\
\hline & Arrive WHC; \\
\hline \multirow[t]{2}{*}{$9: 00 \cdot 10: 00$} & Securily ID Badges \\
\hline & Securily ID Badges \\
\hline \multirow[t]{2}{*}{$, 10: 00-11: 00$} & Preliminary Briefing \\
\hline & Preliminary Brieting \\
\hline \multirow[t]{2}{*}{$11: 00-12: 00$} & Preliminary Brieling \\
\hline & Preliminary Brlefing \\
\hline \multirow[t]{2}{*}{$12: 00-1: 00$} & Lunch \\
\hline & Lunch \\
\hline \multirow[t]{2}{*}{$1: 00-2: 00$} & HGET \\
\hline & HGET \\
\hline \multirow[t]{2}{*}{$2: 00-3: 00$} & HGET \\
\hline & HGET \\
\hline \multirow[t]{2}{*}{$3: 00-4: 00$} & HGET \\
\hline & HGET \\
\hline$-4: 00 \cdot 5: 00$ & $\mathrm{HGET}$ \\
\hline
\end{tabular}

$04 / 15 / 96$.

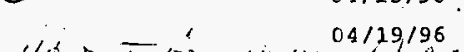
Tuesday Time Plan $8: 00-9: 00$ 9:00-10:00 Collecl and Slage VEA Equipmenl

\begin{tabular}{ll} 
10:00 - 11:00 Collecl and Stage VEA Equipment \\
\cline { 2 - 3 } Collecl and Stage VEA Equipment
\end{tabular} $11: 00-12: 00$

$12: 00-1: 00$

$1: 00-2: 00$

$2: 00 \cdot 3: 00$

$3: 00 \cdot 4: 00$

4:00-5:00

Arrive WHC

Collecl and Slage VEA Equipment

Collecl and Slage VEA Equipment

2X VEA Sile Survey

2X VEA Site Survey Lunch Lunch

Trial CPT Push $2 \times$ Sile Trial CPT Push $2 X$ Site

Trial CPT Push $2 X$ Site Trial CPT Push $2 X$ Sile Trial CPT Push $2 X$ Site Debreif $2 \times$ Sile CPT Push Debreif $2 X$ Sile CPT Push

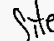

walk

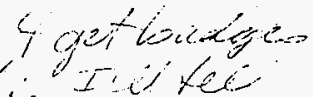

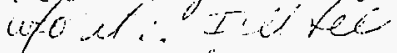

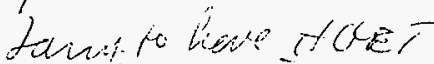

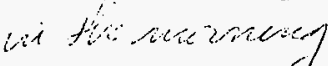<smiles>CC(C)(C)OCCO</smiles>

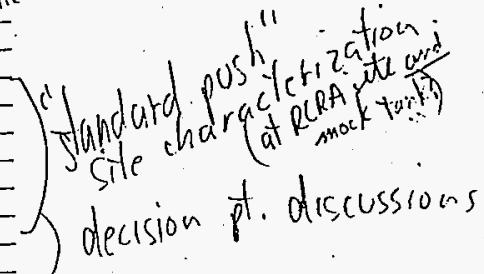
First Milestone Go-Ahead with $2 X$ VEA

\section{Wednesday}

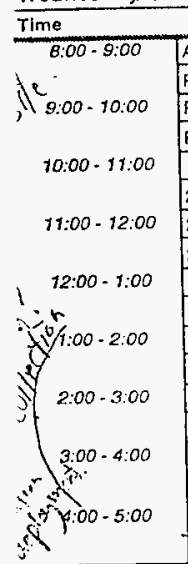

Friday.

\begin{tabular}{|l}
\hline Arrive WHC \\
\hline Pre Deployment Meeting \\
\hline Pre Deployment Meeling \\
\hline Pre Deployment Meeling \\
\hline
\end{tabular}

Start 2X'VEA Push

2X VEA Fush

2XVEA Push

2XVEA Fush

Lunch

Lunch

2X VEA Push / Eleclrical Tesl

$2 X$ VEA Push / Eleclrical Tes!

2XVEA Push / Electrical Test

$2 X$ VEA Push / Eleclrical Tes!

$2 X$ VEA Push / Electrical Tes!

$2 \times$ VEA Push / Electrical Tes!

Debreif / Second Milesto

Go-Ahead $\$ 2 X$ VEA

$$
\text { " go-atis }
$$

Thursday

Time Plan

\begin{tabular}{|c|c|}
\hline \multirow[t]{2}{*}{$8: 00 \cdot 9: 00$} & Arrive WHC \\
\hline & Breiting Pie $12 \times$ VEA Deployment \\
\hline \multirow[t]{2}{*}{$9: 00-10: 00$} & Brelfing Pre $12 X$ VEA Deploymenl \\
\hline & Breiling Pre $12 X$ VEA Deployment \\
\hline \multirow[t]{2}{*}{$10: 00-11: 00$} & Site Survey 12 XVEA \\
\hline & Site Survey 12 XVEA \\
\hline \multirow[t]{2}{*}{$11: 00-12: 00$} & Site Survey $12 X$ VEA \\
\hline & Site Survèy $12 X$ VEA \\
\hline \multirow[t]{2}{*}{$12: 00 \cdot 1: 00$} & Lunch \\
\hline & Lunch \\
\hline \multirow[t]{2}{*}{$1: 00 \cdot 2: 00$} & Slage $12 \times$ VEA Equipment \\
\hline & Stage $12 \times$ VEA Equipment \\
\hline \multirow[t]{2}{*}{$2: 00 \cdot 3: 00$} & Slage 12X VEA Equipment \\
\hline & Slage $12 X$ VEA Equipment \\
\hline \multirow[t]{2}{*}{$3: 00-4: 00$} & Slage 12X VEA Equipmen! \\
\hline & Slage 12X VEA Equipment \\
\hline \multirow[t]{2}{*}{$4: 00 \cdot 5: 00$} & Stage 12X VEA Equipment \\
\hline & Stage $12 \times$ VEA Equipmenl \\
\hline
\end{tabular}

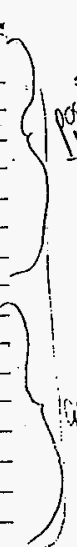

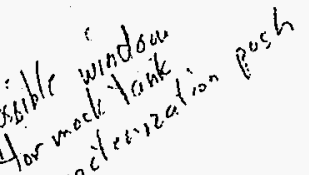
dian $a^{2}$

\begin{tabular}{|c|c|}
\hline Time & Plan \\
\hline $8: 00-9: 00$ & Arrive WHC \\
\hline & 12X VEA CPT Push \\
\hline $9: 00 \cdot 10: 00$ & $12 \times$ VEA CPT PUSh \\
\hline & $12 \times$ VEA CPT Push \\
\hline $10: 00-11: 00$ & $12 \times$ VEA CPT Push \\
\hline & $12 \times$ VEA CPT Push \\
\hline $11: 00 \cdot 12: 00$ & $12 \times$ VEA CPT Push \\
\hline & 12X VEA CPT Push \\
\hline $12: 00 \cdot 1: 00$ & Lunch \\
\hline$\rightarrow$ & Lunch \\
\hline
\end{tabular}
Friday - (continued)

Time

Yrst." Time Plan

$1: 00 \cdot 2: 00$
$2: 00 \cdot 3: 00$
$3: 00 \cdot 4: 00$
$4: 00 \cdot 5: 00$

Decision to Push First VÉA at $12 X$ Site Push First VEA al 12X Site

Push Firs! VEA al $12 X$ Sile

Push First VEA al $12 X$ Site

Push First VEA at 12X Sile

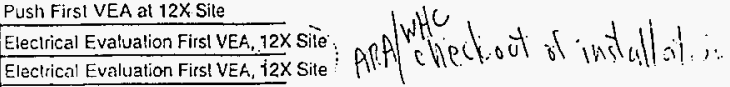
b. fileslane Go. Ahead 12X VEA Deploymenl 


\section{DISTRIBUTION SHEET}

\begin{tabular}{|c|c|c|c|c|c|}
\hline To & \multirow{2}{*}{\multicolumn{3}{|c|}{$\begin{array}{l}\text { From } \\
\text { S. M. Narbutovskin }\end{array}$}} & \multicolumn{2}{|l|}{ Page 1 of 1} \\
\hline DISTRIBUTION & & & & \multicolumn{2}{|c|}{ Date March 6, 1996} \\
\hline \multirow{2}{*}{\multicolumn{4}{|c|}{$\begin{array}{l}\text { Project Title/Work Order } \\
\text { Electrical Resistivity Tomography for Early Vadose Leak } \\
\text { Detection Under Single Shell Storage Tanks. WHC-SD-EN-TP-057, } \\
\text { Rev. } 0\end{array}$}} & \multicolumn{2}{|c|}{ EDT No. 610753} \\
\hline & & & & \multicolumn{2}{|l|}{ ECN No. } \\
\hline Name & MSIN & $\begin{array}{l}\text { Text } \\
\text { With } \\
\text { All } \\
\text { Attach }\end{array}$ & $\begin{array}{l}\text { Text } \\
\text { Only }\end{array}$ & $\begin{array}{l}\text { Attach. / } \\
\text { Appendix } \\
\text { Only }\end{array}$ & $\begin{array}{c}\text { EDT/ECN } \\
\text { Only }\end{array}$ \\
\hline D. F. Iwatate & H5- 09 & $x$ & & & \\
\hline S. M. Narbutovskin & $\mathrm{H} 6-06$ & $x$ & & & \\
\hline J. S. Schmid & H6-06 & $x$ & & & \\
\hline T. C. Stone & $B 1-10$ & $x$ & & & \\
\hline M. D. Sweeney & $\mathrm{H} 6-06$ & $x$ & & & \\
\hline W. R. Thackaberry & $\mathrm{H} 6-32$ & $x$ & & & \\
\hline M. T. York & \multirow{2}{*}{$\begin{array}{l}\text { H6-29 } \\
\text { A3-88 }\end{array}$} & $x$ & & & \\
\hline Central Files & & $x$ & & & \\
\hline
\end{tabular}

